University of Ukraine. VO Sukhomlinsky. Seriya ${ }^{2}$ stor.nauki, $3.35,262-268$. (in Ukr.)

38. Shityuk, M. \& Nazarova K. (2012). The Holodomor 1932 1933 rokiv in Ukraine in the modern history (1986-2009 fry). Mykolaiv, 228. (in Ukr.)

39. Yashchuk P. (2012). Malovivchen aspects of the genocide of the famine in Ukraine. Mykolaiv, 217-234. (in Ukr.)

40. Retrieved from: HYPERLINK "http:// memorialholodomor.org.ua/" http://memorialholodomor.org.ua/ 41. Retrieved from: HYPERLINK "https://www.segodnya.ua/ ukraine/cbu-nashla-esh che-cotnju-vinovnikovholodomora.html" https://www.segodnya.ua/ukraine/cbunashla-eshche-cotnju-vinovnikov-holodomora.html

42. Retrieved from: https://www.radiosvoboda.org/a/ 1889977.html

\section{Y. Kalakura}

\section{ANTHROPOLOGICAL APPROACH IN RESEARCHES OF THE GENOCIDE- HOLODOMOR IN UKRAINE 1932-1933}

Introduction. The essence of the anthropological approach and its features in the researches of the Holodomorgenocide of 1932-1933 in Ukraine as the greatest humanitarian catastrophe of the twentieth century is explained in the article. With an ethnic color, shows its relevance and importance in the context of civilization comprehension of the historical process, the transition from the history of events to the history of people.

Results. On the basis of the system analysis of the problem, three segments of the Holodomor anthropology are outlined: a) victims (dead and injured); b) perpetrators (customers, organizers and executors of a crime); c) memory carriers (witnesses and witnesses of events, benefactors, as well as researchers of the tragedy). Each of these segments is associated with specific people who need to be named by name. From this angle, the main historiographical periods of the human-learned study of the Holodomor are identified, and it is shown how each of them deepened understanding of its causes, nature, territory of distribution and consequences for several generations of Ukrainians.

Originality. Synthesis of the achievements of Ukrainian and foreign researchers regarding the motives of the communist regime's policy aimed at organizing an artificial Holodomor, comparing contemporary interpretations of the demographic, moral and psychological and mental losses of the Ukrainian people, the inability of some authors to undermine their scale allowed to trace the leading tendencies of accumulation of anthropological knowledge, to identify existing gaps, outline the discussion issues in the study of the problem, formulate a series of proposals for further studios and. It is about the need to continue work on the creation of the National Book of Memory, more active involvement of students and post-graduate students in the anthropological issues of the Holodomor, the intensification of genealogical studies, the abolition of any barriers and restrictions on access to metric books postponed in archival institutions. The emphasis on human-centeredness, the announcement of new research results should be rooted in annual nationwide and regional conferences on the Holodomor. The Ukrainian Institute of National Memory and the National Museum of the Holodomor Victims Memorial it would be advisable, together with the Holodomor Research Association, to initiate the creation of a research center for the Holodomor Genocide and the establishment of a magazine quarterly in paper and electronic format under the conditional name "Candle of Memory".

Key words: Holodomor-genocide, anthropological turn, Ukrainian historiography, repressive regime, demographic losses, post-genocidal syndrome, periodization, memorialization of memory, civilizational approach.
УДК 94:304.4(477.43/.44-22) «192» DOI: $10.31651 / 2413-8142-2018-20-59-63$

Н.П. Кузьмінець

кандидат історичних наук, доиент кафедри історії та культури Украӥни Вінницького державного педагогічного університету імені М.Коиюбинського

\section{БІЛЬШОВИЗАЦІЯ КУЛЬТУРНО-ОСВІТНЬОї СФЕРИ У ПОДІЛЬСЬКОМУ СЕЛІ У $1920-X$ РОКАХ}

У статті охарактеризовано найголовнімі культурно-освітні заклади на селі, які стали провідними ідеологічними иентрами на Поділлі; показано головні заходи більшовизачї селянства через мережу сільських будинків та хат-читалень, визначено приничии $i$ механізми їхньої діяльності та показано їхній влив на пролетаризацію подільського селянства. Саме вони сприяли формуванню серед широких народних мас т. зв. пролетарської культури і залученню їх до сочіалістичного будівниитва.

Ключові слова: Поділля, більшовизачія, селянство, сільський будинок, хата-читальня, політосвітня робота.

Постановка проблеми. За сучасних умов розбудови демократичної держави зростає інтерес дослідників та громадськості до історії українського селянства. Важливе місце серед питань новітньої історії України посідає проблема соціально-культурної політики на селі. Соціально-культурна політика держави визначає характер та основні критерії розвитку суспільства, які повинні враховувати традиції, звичаї та менталітет народу. У таких реаліях посилюється інтерес до історичного досвіду вирішення питань, що стосуються культурноосвітнього життя українського села. Культурноосвітня робота $є$ важливим складником у структурі суспільної організації. Нині, враховуючи як позитивний, так і негативний історичний досвід 1920-х рр., необхідно створити належні умови для культурно-освітньої діяльності, що сприятиме духовному й інтелектуальному зростанню нації, формуванню національної еліти. Важливим $\epsilon$ вивчення порушеної нами проблеми у регіональному розрізі, зокрема на прикладі Поділля (сучасна Вінницька і Хмельницька області) - великому аграрному краї, більшість населення якого становили селяни. Поділля сповна відчуло на собі усі «принади» більшовизації культурно-освітньої сфери на селі.

Аналіз останніх досліджень і публікацій. Проблеми культурно-освітньої політики радянської влади в 20-х рp. ХХ ст., проведення різних заходів щодо зміцнення більшовицької влади на селі вже тривалий час цікавить науковців. Численну групу наукової літератури з теми складає радянська історіографія, якій властива ідеологічна заангажованість, пропагандистський і політико-публіцистичний характер. У 20 -ті роки XX ст. висвітленням окремих сюжетів нашої теми займалися партійні та державні діячі, публіцисти, працівники органів народної освіти, які аналізували культурно-освітні процеси на селі [1]. У подальшу радянську добу продовжується дослідження в царині культосвітньої роботи на селі [2]. Окрему групу наукових праць складають дослідження сучасної історіографії історії України, для яких характерне вироблення нових концептуальних 
засад. Інтерес сучасних дослідників до питань розвитку українського села у 1920 -ті роки свідчить про те, що ця тема не є вичерпаною і тому залишається чимало відкритих питань. Одним із аспектів розвитку українського села у зазначений період $є$ процеси суспільного і культурного розвитку, роль яких важко переоцінити. Аналіз їх знаходимо у працях істориків, які займалися дослідженням розвитку українського села у 1920-ті роки [3]. Тема викликала інтерес і у подільських дослідників, однак, спеціального видання так і не було створено [4]. Аналіз загального стану наукової розробки проблеми свідчить про те, що подальше вивчення цієї теми у регіональному розрізі $\epsilon$ актуальним.

Автор статті ставить за мету схарактеризувати організаційне оформлення та діяльність різних культурно-освітніх установ у подільському селі, зокрема, показати роль мережі сільських будинків (сільбудів) та хат-читалень в більшовизації населення краю.

Виклад основного матеріалу. Культурно-освітня робота на селі в перші десятиліття радянської влади була тісно пов'язана зі становленням та практичним функціонуванням розгалуженої мережі селянських будинків та хат-читалень в сільських місцевостях УСРР, де особливе місце, з огляду на аграрний характер, посідало Поділля. Діяльність більшовицької влади в 1920-х роках характеризується жорсткою ідеологізацією усієї культурно-просвітницької роботи на селі. Остання не була для більшовицького режиму самоціллю, а підпорядковувалася цілком прагматичним завданням ідеологічного обробітку населення. Вона завжди проводилася у вигляді політпросвітницької діяльності.

У 1920-ті роки фактично єдиним місцем і формою культурно-освітньої практики на селі (крім шкіл) стали сільські будинки і хати-читальні. В Україні Управління селянськими будинками було створено згідно 3 постановою Колегії Наркомзему від 1 листопада 1920 p. і розпочато діяльність 31 грудня 1920 р. Станом на 1921 р. в Україні діяло 210 селянських будинків [5, 130]. Основна мета сільбудів полягала в культурному поєднанні незаможного селянства та сільського пролетаріату з пролетаріатом міста в єдину трудову сім'ю. Сільбуди повинні були популяризувати колективні форми господарювання і на основі соціалістичної культури та економічної зацікавленості незаможного селянства задовольняти культурні потреби мас. Вони працювали під ідейним керівництвом відділів парткомів КПУ на селі, а також частково на підставі вказівок земельних та освітніх органів радянської влади $[6,122]$. Широка робота 3 організації республіканської мережі розпочалася після 1 грудня 1920 р., коли було створене Всеукраїнське управління селянськими будинками. Тоді формувалися сільбуди декількох видів: сільські, волосні, повітові і губернські. Губернські й повітові селянські будинки мали такі відділи: загальноадміністративний з бухгалтерією, інформаційне бюро, господарський і політико-просвітний з музеєм, бібліотекою, читальнею, театром та кінематографом $[7,97]$.

У 1921 р. були організовані та функціонували губернські управління селянськими будинками в усіх губернських містах. Оскільки виборні органи радянської влади в Подільській губернії були сформовані пізніше, ніж у інших регіонах УСРР, вони приступили до реалізації зазначених вимог із певною затримкою. Проте змушені були діяти активно, адже підтримка подолянами масового повстанського руху, спрямованого на відновлення державної незалежності України, поставила перед місцевою владою гостру необхідність зміцнення «ідеологічного фронту на селі». Знаряддями, через які органи політосвіти мали реалізовувати зазначені завдання, постановою РНК УСРР від 19 квітня 1921 р. «Про селянські будинки» визначалися сільбуди [8, 9]. Вони покликані були замінити ідейно ворожі 398 осередків «Просвіти», які діяли в регіоні. На той час сільбудів на Поділлі ще не було.

Місцева влада встигла організувати 743 хатичитальні. Вони були початковою формою селянських будинків їх працівники проводили лекції та бесіди, колективне читання книжок і газет, антирелігійні кампанії, здійснювали бібліотечну і шкільну роботу. Крім того, як зазначалося в звіті губполітосвіти за вересень 1921 р., бібліотеки, клуби, хати-читальні тощо тоді існували лише на папері. Влада спершу спробувала організувати народні будинки, покликані пропагувати комуністичні погляди під прикриттям розвитку народної творчості. Однак подоляни швидко розібралися в їхній суті. Як наслідок, до кінця 1922 р. в губернії було створено лише 21 такий будинок [9, 317].

Для більшовиків дедалі ставало очевиднішим, що будь-яка реорганізація політосвітніх закладів не дасть бажаного ефекту без підриву «Просвіти», осередки якої секретар губкому Чернявський назвав «організуючими центрами контрреволюції». Пленум вирішив провести чергову їхню чистку. На практиці це означало ліквідацію або примусове перетворення осередків «Просвіти» в сільбуди. Так, із 662 «Просвіт», які діяли в краї станом на 1 жовтня 1922 р., до січня 1923 залишилося 499, на кінець березня - 216, а до 1 січня 1924 не залишилося жодної [10, 59]. Однак це не призвело до збільшення кількості сільбудів, хатчиталень, народних будинків, бібліотек і клубів, які мали замінити «Просвіти».

У травні 1923 р. постановою РНК УСРР вся мережа сільбудів республіки була передана Народному Комісаріату освіти. Окружні й районні сільбуди стали організаційними і методичними центрами політосвітньої роботи на селі. Оскільки сільбуди в основному орієнтувалися на молодь, вони й мали забезпечувати як ¥ї виховання в комуністичному дусі, так і контроль за їі дозвіллям. Організаційним центром політико-освітньої роботи для міста був клуб, а для села - селянський будинок. Членом сільбуду міг стати кожний громадянин, який мав право виборів до Рад (члени профспілок, КНС, бідняки, середняки), а також молодь у віці від 14 до 18 років. Вони будувалися за принципом добровільного членства $[11,146] .3$ липня 1921 p. сільбуди були переведені на самозабезпечення. Імм надавалося право брати плату за використання приміщень, використовувати приписані до сільбудів радгоспні майстерні, сільськогосподарські пункти, політосвітні заклади, брати плату за вистави, концерти. Окружні сільбуди змушені були в своїй структурі утримувати їдальні, готелі та постоялі двори. В умовах недороду 1924 р. спостерігається скорочення їхньої мережі впродовж року на 121 будинок - до 378 [12, 405]. 
Підсумок етапу становлення сільбудів у грудні 1924 р. підбила президія губвиконкому. Заслухавши звіт голови губсільбуду, вона констатувала недостатнє охоплення подолян селянськими будинками (один сільбуд припадав у середньому на 5 сіл). Було поставлено завдання впродовж зими на третину збільшити кількість членів сільбудів - до 100 тис. Як негативне явище члени президії сприйняли «культурологічний ухил»у роботі сільбудів, що деструктурно впливало на «політичну, виробничу та сільськогосподарську роботу». Було поставлено завдання негайно виправити ситуацію.

Доленосне значення для подальшої долі сільбудів мало рішення взяти на бюджетне фінансування губсільбудинку 5 окружних, 93-х районних і 93 сільських сільбудів і понад сто хат-читалень. Звільнення від непрофільної діяльності дозволило сільбудам зосередитися на культурно-освітній роботі. Була реанімована діяльність драматичних, співочих, сільськогосподарських гуртків, бібліотек, курсів ліквідації неписьменності тощо. Це сприяло зростанню привабливості й розширенню як їхньої мережі, так і чисельності $[9,320]$. У середньому у $1925-1928$ pp. мережа сільбудів і хат-читалень у кожній з округ Поділля збільшилася на $30 \%$, а кількість членів - на $20 \%[13,79]$. Визначити точну кількість культосвітніх установ досить складно через різну інформацію. Зокрема, інформаційний відділ Вінницького окрвиконкому в звіті про культурну роботу за 1927 р. доповідав, що в окрузі діє 86 сільбудів проти 66 в 1926 p. і 408 хат-читалень проти 330. Статистичні дані по цій окрузі говорять про 104 сільбуди і 264 хатичитальні $[10,80]$.

31927 р. мережа культурно-освітніх установ села зазнала змін. Було скасовано райсільбуди та запроваджено районну інспектуру. Культурно-освітні установи розподілялися на червоний куток, хатичитальні, опорні сільбуди. Сільбуд вважався широкою громадською організацією села і повинен був мати міцний зв' язок із усіма сільськими організаціями. При сільбуді були бібліотеки, в яких містилися книги 3 сільського господарства, земельного права, кооперації, географії, історії, політграмоти тощо. Постійно проводилися своєрідні «чистки» бібліотек із метою не допустити наповнення бібліотек Поділля «монархічною та антирадянською літературою». Так, у звіті Вінницької окрполітосвіти «Про підсумки політосвітньої роботи до 10-річчя Жовтня» зазначалося, що станом на 1927 р. фонди бібліотек були вичищені на 95 \%. Чистку планували завершити в 1928 p. [14, 19]. Вилучені книги частково знищувалися, частково передавалися до окружних архівів.

Створювати нові книгозбірні можливості майже не було, а тому з 1924 р. почали створювати бібліотекипересувки. Вони постачали книгами так звані червоні кутки, які створювалися в невеликих селах. Саме там уголос читали селянам книги й організовували їх обговорення. Зрозуміло, що література була визначеного партією політичного спрямування і тому селяни перебували під постійним ідеологічним контролем радянської влади. Фонди більшості радянських хат-читалень були практично однаковими. Ix основу складали книги "Україна в руїнах», «Жовтнева революція», «Как крестьяне отобрали свою землю», «Задачи Коммунистической партии», а також твори В. Леніна $[15,220]$. Газети часто передплачувала сільрада або сільбуд. Пресу могли читати у хатах-читальнях, де селяни збиралися постійно. Тут також проводили політичні та сільськогосподарські кампанії. Селяни могли послухати доповіді про регіональну специфіку сільського господарства, про більшовицьку економічну політику, проводили екскурсії на дослідні станції. При хатах-читальнях було організовано сільськогосподарські гуртки. Вони були найголовнішою формою агротехнічної пропаганди.

Для реалізації економічних завдань при сільбудах утворювалися ремонтні майстерні, прокатні пункти техніки, дослідні станції, поля, ветеринарні й злучні пункти, амбулаторії та зразкові господарства, кустарні майстерні, кооперативні крамниці, громадські їдальні, насіннєві магазини тощо. Однак партійне керівництво перед сільбудами і хатами-читальнями першочерговим завданням висувало необхідність стати осередками політичної агітації, а вже потім центрами культурно-освітньої роботи на селі. Культурно-освітня робота у подільському селі проводилася також із залученням до неї бібліотек, хоча бібліотечна справа перебувала на досить низькому рівні. Найкраще вона була розвинена у Вінницькій, Могилів-Подільській, Тульчинській та Гайсинській округах. Так, у Вінницькій окрузі на кінець 1922 р. діяло 8 бібліотек, в яких нараховувалося 21740 книжок $[16,130]$. Загалом на Вінниччині на 1 січня 1925 p. діяло 139 бібліотек, лише в сільських бібліотеках налічувалося 158055 книжок $[17,96]$.

Одним із напрямів діяльності сільбудів та інших культурно-освітніх закладів на селі було впровадження нових радянських свят. Активно пропагувалися такі обряди, як червоне весілля, червоні хрестини та похорони. Пріоритетним завданням була допомога партійним і радянським органам у підготовці та проведенні революційних свят: днів лютневої революції та Паризької комуни, 1 травня, річниць жовтневої революції. Подоляни читали лекції та проводили бесіди призначені відповідному святу, проводили зустрічі з учасниками різних подій, влаштовували святкові концерти, привітання учасників різноманітних форумів. Одним із популярних урегіоні свят було вшанування Т. Шевченка, хоча говорили про нього не стільки, як про поета, а я про видатного революціонера $[18,2]$.

Висновки. Загалом, не заперечуючи часткової позитивної ролі хат-читалень і селянських будинків у культурно-освітньому процесі на селі, відзначимо, що вони були насамперед потужним засобом ідеологічного впливу на селянство. Як тільки більшовики встановили контроль над Україною, вони негайно включили селянство в орбіту комуністичного проекту. Репресивна політика радянської тоталітарної держави щодо українського селянства була спрямована проти розбудови на селі української державності. Сумнозвісна більшовицька політика щодо селянства завдала величезної шкоди його моральному та інтелектуальному потенціалу, деформувала його національну свідомість. За допомогою хат-читалень і селянських будинків як інструментів ідеологічного радянського штурму українського села знищувалися цілі пласти національної культури і духовності. Більшовицька тоталітарна система, що формувалася в Україні, як і 
на Поділлі, жорстоко переслідувала будь-які відступи від марксистсько-ленінської ідеології, обстоюючи своє по-насильницькому встановлене панування над народом, більшість якого становило селянство.

\section{Список використаної літератури та джерел:}

1. Гринько Г.Ф. Основные задачи советского строительства в области просвещения / Г.Ф. Гринько . - Х.: ДВУ. - 1920 - 126 с.; Волобуєв М. Хата-читальня та сельбуд М. Волобуев // Селянський будинок. - 1925. - №1; Канцелярський П. Що таке сельбуд П. Канцелярський. - Х.: ДВУ, 1926. - 32 с.; Багмут I.А Червоні кутки на селі (куткові хати-читальні) I.А. Багмут. - Харків: Держвидав України. -1927. - 72 с 2. Андреева М.С. Политико-просветительская работа в деревне в конце восстановительного периода (19241925 гг.) / М.С. Андреева. - М.: Госуд. изд-во к-нопросветительной литературы, 1953. - 22 с.; Шевчук Г.М Культурне будівництво на Україні у 1921 - 1925 роках Г.М. Шевчук . - К, 1963. - 435 с.; Чайчук Р.Д. Про роль сільських клубів у політичному вихованні селян Р.Д. Чайчук// Український історичний журнал. - 1963. №2. - С. 108-110; Алексеева Н.Л. Культура нового села. - Львів : Каменяр, 1974; Юрченко А.В. Розвиток мережі сільбудів і хат читалень на Україні (1921-1925 pp.) А.В. Юрченко // Український історичний журнал. 1978. - №11. - C. 95-100.

3. Бондарчук П.В. Національно-культурна політика більшовиків в Україні на початку 1920 -х років / П.В. Бондарчук. - К., 1998. - 45 с.; Кукса Н.Г. Діяльність культурно-освітніх закладів в українському селі в 1924 1928 рр. / Н.Г. Кукса // Український селянин. - 2003. Вип. 7. - С. 43-44; Земзюліна Н.І. Діяльність сільбуду з формування комуністичної свідомості українських селян (1921-1929 рр.) / Н.І. Земзюліна// Український селянин. 2006. - Вип. 10. - С. 145-148; Маркова С.В. Суспільнополітичні зміни в українському селі у контексті формування комуністичної системи (1917-1933рр.). Кам'янець-Подільський: Видавець ПП Звалейко Д.Г. 2015. - 544 с.; Морозов А.Г. Селянський рух опору посиленню тоталітарного режиму в Україні 1920-х рр. А.Г. Морозов, О.М. Абразумова // Гуржіївські історичні читання : зб. наук. пр.. Випуск 4. - Черкаси: Вид-во Черкаського національного університету ім. Б. Хмельницького, 2011. - С. 242-244.

4. Григорчук П.С. Деякі особливості аграрних відносин в Подільській губернії на початку 20-х pp. ХХ ст. П.С. Григорчук // Наукові записки Вінницького державного педагогічного університету імені М. Коцюбинського. - Вип. ХХ. Серія: Історія. - Вінниця, 2012. - С. 200-204; Кузьмінець Н.П. Сільські ради Поділля на початку 20-х pp. ХХ ст./ Н.П. Кузьмінець// Наукові записки Вінницького державного педагогічного університету ім. М. Коцюбинського. - Серія: Історія. Вінниця, 2008. - Вип. 13. - С. 275-277; Лойко О., Культурно-освітня робота серед сільського населення Вінниччини в 1921-1928pp. / О.О. Лойко // Наукові записки Вінницького державного педагогічного університету ім. М. Коцюбинського. Серія: Історія. - Вінниця. 2001. - Вип. 3. - С. 90-95; Мельничук О.А. Комнезами на Поділлі П.С. Григорчук, О.А. Мельничук. - Вінниця, 2001. $160 \mathrm{c}$.

5. Ладига Л.І. Діяльність сільбудів в Україні у 20-х pp. XX ст. / Л.І. Ладига// Вісник Луганського національного університету ім. Т. Шевченка. Історичні науки. - Ч.1. 2012. - C. $125-132$.

6. Центральний державний архів громадських об'єднань України, ф.1, оп.20, спр. 631, арк. 122.

7. Юрченко А.В. Розвиток мережі сільбудів і хат-читалень на Україні (1921-1925 роки) // Український історичний журнал.- 1978. - №11. - С. 96-100.

8. Богуцький Ю. Українське суспільство першої половини XX століття в аспекті організації та самоорганізації культурно-мистецької діяльності / Ю. Богуцький // Культурологічна думка: Щорічник наукових праць. - К.:
Інститут культурології Національної академії мистецтв України. - 2012. - №5. - С. 7-12.

9. Олійник М.П. Поділля в роки нової економічної політики: політичні, соціально-економічні та культурнодуховні процеси (1921-1928). - Кам'янець-Подільський, 2015. -546 c.

10. Державний архів Вінницької області (далі ДАВіО), ф.1, оп 1, спр.3, 281 арк.

11. Земзюліна Н.І. Діяльність сільбуду з формування комуністичної свідомості українських селян (19211929 рр.) / Н. Земзюліна // Український селянин / ред. А.Г. Морозова. - Черкаси: Черкаський національний університет ім. Б. Хмельницького, 2006. - Вип. 10. C. $145-148$

12. Поділля в період відбудови народного господарства (1921-1925 рр.) : збірник документів і матеріалів / ред. I.О. Пшук, А.Г. Бабено, С.Я. Вініковецький [та ін.]. Вінниця, 1957. -560 с.

13. Социалистическое строительство на Виннитчине: Документы и материалы: (1921-1941) / ред Г.Я. Буртяк [и др.]. - Одеса : Маяк, 1987. - 272 с.

14. ДАВіО, ф. 29, оп.1, спр.290, арк. 19.

15. ДАВіО, ф. Р-200, оп.1, спр.9, арк. 229

16. ДАВiО, ф. 254, оп.1, спр.195, арк. 135

17. Бюлетень Подольского статистическкого бюро. -1925. - №2(29). - Винница, 1925. - С. 96

18. Революционный суд // Вісті. Орган губревкому Поділля та губпарткому КП(б)У. - 1921. - №18(93). - 28 січня.

\section{References:}

1. Grinko G.F.(1920). Osnovnye zadachi sovetskogo stroitelstva v oblasti prosveshcheniya [The main tasks of Soviet construction in the field of education]. Kharkiv: State Publishing House of Ukraine(in Ukr.); Volobuyev M.(1925). Khatachytalnia ta selbud[Hut-reading room and Selbud]. Selianskyi budynok,1(in Ukr.);

Kantselyars'kyy P.(1926). Shcho take selbud [What is a country house]. Kharkiv: State Publishing House of Ukraine(in Ukr.);Bagmut I.A.(1927). Chervoni kutky na seli (kutkovi khaty-chytalni)[Red corners in the village]. Kharkiv: State Publishing House of Ukraine(in Ukr.).

2. Andreeva M.S.(1953). Politiko-prosvetitelskaya rabota v derevne $\mathrm{v}$ kontse vosstanovitelnogo perioda (1924-1925 gg.) [Political and educational work in the village at the end of the recovery period (1924-1925) Political and educational work in the village at the end of the recovery period (1924-1925)]. Moskva: Gosudarstvennoe izdatelstvo prosvetitelnoy literaturyi,22. (in Ukr.); Shevchuk G.M. (1963). Kulturne budivnytstvo na Ukraini u 1921 - 1925 rokakh.[ Cultural construction in Ukraine in 1921 - 1925]. Kyiv,435; Chaychuk R.D.(1963). Pro rol silskykh klubiv u politychnomu vykhovanni selian[On the role of village clubs in the political education of peasants] Ukrainskyi istorychnyi zhurnal,2,108110; Alekseeva N.L.(1974). Kultura novogo selà[Culture of the new village]. Lviv: Kameniar. (in Ukr.); Yurchenko A.V.(1978). Rozvytok merezhi silbudiv i khat chytalen na Ukraini (1921-1925 rr.)[ Rozvytok merezhi silbudiv i khat chytalen na Ukraini (1921-1925 rr.)] Ukrainskyi istorychnyi zhurnal,11,95-100. (in Ukr.).

3. Bondarchuk P.V.(1998). Natsionalno-kulturna polityka bilshovykiv v Ukraini na pochatku 1920-kh rokiv.[ Nationalcultural policy of the Bolsheviks in Ukraine in the early 1920's], Kyiv,45, (in Ukr.) ;Kuxa, N.G.(2003) Activities of cultural and educational institutions in the Ukrainian village in 1924-1928 gg. Cherkasy: Ukrainian peasant. (Ukrayins'kyy selyanyn), 7, 43-44 (in Ukr.); Zemzulina, N.I.(2006) Activities of the farm for the formation of the communist consciousness of Ukrainian peasants (1921-1929 gg.). Cherkasy:Ukrainian peasant. (Ukrayins'kyy selyanyn),10, 145-148; Markova S.V. (2015). Suspilno-politychni zminy v ukrainskomu seli u konteksti formuvannia komunistychnoi systemy (1917-1933 rr.) [Social and political changes are in the Ukrainian village in the context of forming of the communist system (1917-1933). Social and political changes are in the Ukrainian village in the 
context of forming of the communist system (1917-1933)]. Kamianets-Podilskyi: Vydavets PP Zvaleiko D.H. KamianetsPodilskyi: Vydavets PP Zvaleiko D.H.(in Ukr.); Morozov, A.H. \& Abrazumova, O.M. (2011). Selianskyi rukh oporu posylenniu totalitarnoho rezhymu v Ukraini 1920-kh rr. [Peasant motion of resistance to strengthening of the totalitarian mode in Ukraine 1920th]. Hurzhiivski istorychni chytannia: [Zb. nauk. pr.]. Vypusk 4. - Cherkasy: Vyd-vo Cherkaskoho natsionalnoho universytetu im. B. Khmelnytskoho (in Ukr.). 4. Hryhorchuk, P.S.(2012). Deiaki osoblyvosti ahrarnykh vidnosyn v Podilskii hubernii na pochatku 20-kh rr. KhKh st.[ Some features of agrarian relations in the Podillya province in the early 20 's of the twentieth century]. Naukovi zapysky Vinnytskoho derzhavnoho pedahohichnoho universytetu imeni M. Kotsiubynskoho,20, 200-204 (in Ukr.);Kuzminets N.P.(2008). Silski rady Podillia na pochatku 20-kh rr. KhKh st.[ Village councils of Podillia in the early 20's of the twentieth century], Naukovi zapysky Vinnytskoho derzhavnoho pedahohichnoho universytetu imeni M. Kotsiubynskoho, 13,275-277(in Ukr.); Loiko O.(2001). Kulturno-osvitnia robota sered silskoho naselennia Vinnychchyny v 1921-1928 rr.[ Cultural and educational work among the rural population of Vinnytsya in 1921-1928 gg.], Naukovi zapysky Vinnytskoho derzhavnoho pedahohichnoho universytetu imeni $M$ Kotsiubynskoho, 3, 90-95 (in Ukr.); Melnichuk O.A.,\& Grigorchuk P.S.(2001). Komnezamy na Podilli.[ Comes in Podillia]. Vinnytsia (in Ukr.).

5. Ladyha L.I.(2012). Diialnist silbudiv v Ukraini u 20-kh rr. KhKh st. [ The activities of farm farms in Ukraine in the 20's of the twentieth century]. Visnyk Luhanskoho natsionalnoho universytetu im. T. Shevchenka. Istorychni nauky,1,125-132. 6. Tsentralnyj derzhavnyj arkhiv hromadskykh objednan Ukrainy (dali-TsDAHOU. - F.1.-O.20. - Spr.621. - Ark.122. 7. Yurchenko AV.(1978). Rozvytok merezhi silbudiv i khatchytalen na Ukraini.[ Development of a network of agricultural farms and hat-readers in Ukraine]. Ukrainskyi istorychnyi zhurnal,11,96-100 (in Ukr.)

8. Bogutsky Yu (2012). Ukrainske suspilstvo pershoi polovyny $\mathrm{KhKh}$ stolittia $\mathrm{v}$ aspekti orhanizatsii ta samoorhanizatsii kulturno-mystetskoi diialnosti[Ukrainian society of the first half of the twentieth century in the aspect of organization and self-organization of cultural and artistic activity]. Kulturolohichna dumka: Shchorichnyk naukovykh prats, 5,7-12 (in Ukr.).

9. Oliynyk M.P.(2015). Podillia v roky novoi ekonomichnoi polityky: politychni, sotsialno-ekonomichni ta kulturnodukhovni protsesy (1921-1928). [ Podillya in the years of the new economic policy: political, socio-economic, and culturalspiritual processes (1921-1928]. Kamianets-Podilskyi, 546. 10. Derzhavnyi arkhiv Vinnytskoi oblasti (dali - DAViO). F.1. - Op1. - spr.3. - ark. 59.

11. Zemzulina N.I.(2006) Activities of the farm for the formation of the communist consciousness of Ukrainian peasants (1921-1929 gg.). Cherkasy:Ukrainian peasant. (Ukrayins'kyy selyanyn),10,145-148 (in Ukr.).

12. Pushuk O.I. (1957) Podillia v period vidbudovy narodnoho hospodarstva (1921-1925 rr. ): Zbirnyk dokumentiv i materialiv [Podillya during the rebuilding of the national economy (19211925 gg.): Collection of documents and materials], Vynnytsa(in Ukr.).

13. Volovik V.F(1987) Sotsialisticheskoe stroitelstvo na Vinnitchine: Dokumentyi i materialyi : (1921-1941)[ Socialist construction in Vinnytsia: Documents and materials: (19211941)]. Odesa: Mayak(in Ukr.).

14. DAViO. - 29, 1, 290, 19.

15. DAViO. - 200, 1, 9, 229

16. DAViO. - 254, 1, 195, 135.

17. Biuleten Podolskoho statystycheskkoho biuro (1925). 12(29). Vynnytsa (in Ukr.).

18. Revolyutsionnyiy sud(1921). Visti. Orhan hubrevkomu Podillia ta hubpartkomu KP(b)U. Visti. Orhan hubrevkomu Podillia ta hubpartkomu KP(b)U, (in Ukr.).

\section{N. Kuzmynets}

\section{BOLSHEVIZATION OF THE CULTURAL- EDUCATIONAL SPHERE IN THE PODILSKY VILLAGE IN THE 1920S}

Introduction. In this article, the author, on the basis of available literature and sources, analyzed the processes of bolshevization of Podilskyi village in the 1920s. In the introduction it is noted that after the seizure of power, the Bolsheviks announced the beginning of the construction of a new society.

The main results of the study can be used in studying the history of Ukraine and the history of Podilia.

Results. The proletarian culture was designed to fulfill the great and responsible task of involving the masses in socialist construction. The network of educational establishments was presented to Podilia primarily by peasant houses and huts-reading rooms, acting in the Podilia village, one of the few means of cultural and educational work in the village. They were supposed to replace the Ukrainian "Enlightenment", whose rural centers were well known since the pre-revolutionary period. It should be noted the numerous organizational and financial difficulties that were on the way to the formation of this network. In the cultural and educational work among the Podilia peasantry prevailed dominant ideology. Hut-reading rooms and village houses were intended to form a loyal citizen's system through the total propaganda. Thanks to state support, rural houses and reading-houses were fixed in the countryside and concentrated around all cultural and educational activities. They concentrated around reading rooms, libraries, museums and became the only centers of culture in the countryside. The Soviet-style hutreader used as leading ideological centers, which were supposed to bring the necessary information to every inhabitant of the most remote corner of Podilskyi village. The Soviet state and the social, cultural and educational organizations that depended on it during the 1920's made every effort to agitate and propagate the existing system and sought to capture as much of their number of peasants as Podilia.

Originality. The originality of the study is that the author, on the basis of new sources, considers the under-studied problem of the role of cultural and educational institutions in the Bolshevisation of the Podilskyi region.

Conclusion. The author came to the conclusion that this problem deserves further study of the role of various cultural and educational institutions in the process of establishing a totalitarian system in the state.

Key words: Podilia, Bolshevization, peasantry, village house, hut-reading room, political science work.

УДК: $930.2(045)=191.2(477.5+476)$

DOI: $10.31651 / 2413-8142-2018-20-63-70$

B.В. Нечитайло

аспірант кафедри суспільних наук, інформаційної та архівної справи Центральноукрайнського начіонального технічного університету

\section{ОБІГ В УКРАЇНІ МОСКОВСЬКИХ ЄФІМКІВ ІЗ ОЗНАКАМИ: НОВІТНЯ ІСТОРІОГРАФІЯ ДОСЛІДЖЕННЯ}

У статті проаналізовано новітні дослідження 3 підготовки та проведення грошової реформи московського ияаря Олексія Михайловича та ї̈ наслідки для Украӥни. Встановлено обласний район із найбільшою концентрацією знахідок «єфімків з ознаками». Висунуто припущення шуодо потенційної імовірності виявлення у складі скарбів фальсифікату часів побутування, або нанесення підроблених клейм на західноєвропейські 